\title{
YARGILAMA HUKUKU KURALLARININ ADALET DEĞERİ ÜZERİNE
}

\author{
Yazan : Prof. Dr. Wolfram HENCKEL \\ Çeviren : Dr. Ergun ÖNEN
}

Hukuk ilmi yazılı kanunlarının muhtevasını açıklamak ve mümkün mertebe kapalı bir hukuk sistemi içine yerleştirmek işiyle yetinemez. Yalnız tarihî tecrübe ve siyasî sorumluluk değil, herşeyden önce ilmî dürüstlük, hukukçuya bilinen hukuk kurallarını incelemeyi ve bunları değerleri yönünden takdir etmeyi emreder. Mer'i hukukun pozitivist yönde yapılan tanımı ile yetinen bir hukuk ilmi, hukuk siyasetinin gerektirdiği ödevlere karșı olan yetersizliği nispetinde politik maksatlı kötü kullanmalara maruz bırakılmış olacaktır. Eğer modern anlamda gerçeğe uygun hukukî esasların yeni baștan düzenlenmesi gerekirse, bu hukuk ilminin kararlı beyanlarda bulunması icap edecektir. Hukuk ilmi Avrupa toplumları içinde ve genel olarak birbirlerine yakın olan milletlerin müșterek yaşayışlarında karşımıza çıkan hukukî haberleșmenin problemlerini çözmeye çalışsaydı, elverişsiz hale gelirdi. Zira muhtelif hukuk sistemlerinin birbirleriyle kıyaslanmasının sadece istatistiki bir değeri olur ve eğer dış görünüşleri bakımından farklı olan hukuk sistemlerinin esasını hangi bileșik değer bükümlerinin teşkil ettiği sorusundan kaçınılacak olursa, her türlü hukukî kıyaslama kösteklenmiş olurdu. Bu sebepten dolayı hukuku yalnız uygulamakla kalmayıp, aynı zamanda bunun üzerinde düşünen hu. kukçu, mevcut hukuk kaidesinin neden başka türlü değil de öyle olduğu sorusunu soracaktır; o, münferit bir hukukî esasın hukuk düzeninin bütünü içinde kendisinden beklenileni yerine getirip getiremediğini ve bunu ne derecede gerçekleştirebildiğini inceleyecektir. Böylece o, son olarak, hukuk kaidesinin adil olup olmadığını veya başka bir deyimle hukukî esasın hukuk fikrine yöneltilmiş bulunup bulınmadığını araştıracaktır. Fakat bu sorunun ilmî şekilde gerekçelendirilecek cevabı, ferdin sübjektif hukukî duygusunu veya adalet hissini ölçü olarak alamaz. Daha çok makûl bir incelemeye dayanabilecek sağlamlıkta objektif kıstaslann bulunması gereke- 
cektir. E'ğer bu suretle hukuk fikrinin muhtevasının bağlayıcı olarak tayiı edilmesi ödevi șart kılınmıș olsaydı, biz kendimizi kaçınılması nümkün olmayan bir șaşkınlık içinde bulurduk.

Hukuk fikrinin muhtevasını zaman kavramı dışında bağlayıcı olarak tespit etmek, şimdiye kadarki hukukçu nesillerine nasip olmamıştır. Zaten bunun gerçekleşmesi bizzat hukuk üzerinde düşïnmeyi de ortadan kaldıracaktır. Zira, aksi halde hukuk ilmi, münferit hukukî prensiplerin, hukuk fikrinin değișir olmayan muhtevasıyla yapılan matematikî bir kıyasından başka bir şey olmayacaktır. Fakat hukuk üzerinde düșünme, daima yaklașmak istediğimiz fakat hiçbir zaman tam olarak erişemediğimiz uzak bir gayeye yöneltilmiş yeni bir ödevdir. Bu itibarla hukuk fikrinin muhteva yönïnden zamanla kayıtlı olmaksızın muteber olarak tayini, sadece :mkânsız değil, devamlı olarak bize yöneltilen isteklerle de bağdaşamaz karakterdedir. Bu, bizim adaleti izafî hale koymak veya onu menfaatlerin bir oyuncağı olarak kabul etmek istediğimiz anlamına gelmemelidir. Çünkü biz bir hukuk ortamının ancak, adalet veya hukuk düşüncesi diye tanımladığımız, zorunlu olarak daima karșımıza çıkacak ve fakat bir kavram olarak belirtilmesi mümkün olmayacak olan bir gayeye yöneltilmiş olması halinde, garçek anlamda bir hukuk düzeni olabileceği esasından hareket edivoruz.

Eğer yargılama hukuku kurallarının adalet değerini araştıracak olursak, karşımıza herşeyden önce, hukuk düzenimizin yargılama hukukuyla koordine ettiğimiz bölümü ile genel olarak hukuk fikri arasında takdirî bir bağlantı kurulup kurulamıyacağı sorunu çıkacaktır. Bu soruyu cevaplandırmak için hukuk fikrinin muhtevasını belirtmemize lüzum yoktur. Biz daha çok yargılama hukuku kaidelerinin hukuk düzenimizin esası olan maddî hukuk prensiplerine uygunluğu derecesinde gayeye erișebiliriz. Bu gibi prensiplerin tarihin akışı içinde denenișleri, değişen sosyal ve ekonomik şartlar karşısındaki elâstikiyetleri ve çeşitli hukuk sistemlerinde durmadan tekrarlanışları bizim gayelerimiz için yeter derecede emriyet sağlarlar. Yargılama hukuku kaidelerini pratik hukuk ahlâkının bilinen esaslarına (1) irca etmekte bașarı sağlanırsa, bu takdirde yargılama hukukumuzun kurallarmm maddî hukuk prensiplerir deki ölçüde hukuk fikrine yöneltilmiş oldukları herhalde ispat edilmiș olacaktır.

(1) Karș. Franz Wieacker, Zum heutigen Stand der Naturrechtsdiskussion, (Tabii hukuk tartışmasının bugünkü durumu üzerine), 1965, s. 7 vd. 
Yargılama hukuku kaideleri için hukuk fikrinin kıstas teşkil edip edemiyeceği şeklindeki bu basit soruda bile üzerinde düşünülmesi gereken problemler saklıdır. Asrımızın ilmî kaynaklarında tanınmış usulcülerin, hayal kırıklığına uğratan cevaplarını buluruz. Friedrich Stein (2) şöyle demektedir : «Fikrimizce yargılama tam manâsıyla, değișen gayeye uygunlukların tesiri altında kalan ve ebedî değerlerden yoksun olan bir 'teknik hukuk'tur». James Goldschmidt (3) - kendi deyimiyle - metafizik bir yargilama hukuku ilmine yönelmeye gayret etmektedir. Bununla o yargilama hukukunu aşan ve hukuk düzeninin bütünü itibariyle gayesi ve onun maddî hukuk ilișkilerine olan tesirleriyle ilgilenen bir araştırma tarzını kastetmektedir. Yargılama hukukunun önemli bir takım tanımlamaları vardır. Bu tanımlamalar bir hukukî sonucun neden uygun olduğu konusunda soru sormadan veya böyle bir sorunun cevabinı vermeden sadece yarglama hukuku ile neyin kastedildiğini tekrar etmektedirler (4).

Maddî hukuk alanında bir hukukî neticenin âdilliği sorununda ekseriya iyi bir çare olan, hukukçu olmayan bir şahsın içgüdüsü, yargılama hukuku sahasında çoğu zaman ișe yaramıyacktır. Dâvayı kaybeden taraf kendisinin zaman zaman maddî hukuka ilişkin ihtimalleri yanlış değerlendirdiği ve meselâ katlanmak zorunda kaldığı bir zararın dâvacıya isnat edilemiyeceği sonucuna varabilirse, bu takdirde onun mantığı, dâvayı sırf şeklî sebeplerle kaybetmiş olmayı bir türlü kabul etmeyecektir. Hakkının sadece bir müddeti kaçırmış olması veya kendisi için olumlu bir ispat vasıtasını zamanında elde edememesi, bir dilekçeyi doğru formüle etmemiş olması veya yanlış olduğu kabul edilen bir hükme karșı temyiz süresinin geçirilmiş bulunulması gibi sebeplerle kaybetmek zorunda kalmayı onun havsalası bir türlü almayacaktır. Yargılamanın disiplinli bir şekilde yürütülmesini sağlamak gayesiyle verilen bir direktif, tek başına, tarafı sakinleştirmeye ve teselli etmeye yetmeyecektir .

Maddî bakımdan doğruluğu hakkında henüz tam bir fikir sahibi olmadan, bir dâvayı sırf şeklî sebeplerden ötürü sonuçlandırmak çoğu "zaman bizzat yargıç için bile endişe verici olmaktadır.

(2) Grundriss des Zivilprozessrechts und des Konkursrechts (Yargilama ve İflâs Hukuku esasları), 1. Basının önsözü, 1921.

(3) Der Prozess als Rechtslage (Hukukî durum olarak yargılama), 1925, s. 150,187 vd.

(4) Örneğin Leo Rosenberg'in yargilama hukuku kitabının (Lehrbuch des deutschen Zivilprozessrechts) (9. Bası, 1961) birçok yerlerinde yapıdığı gibi. 
Bunun içindir ki, kaçırılmış olan usulî müddetlere karşı bir çare olarak düşünülen eski hale getirme dilekçeleri, alt dereceli mahkemelerde kanun koyucunun istediğinden daha cömert bir kabule mazhar olmuşlardır. Dâvayı çabuklaştırmak amacıyla bir tarafın gecikmiş olan taleplerini kabul etmemek, bilhassa iyiniyetli bir yargıç için hiç te kolay olmamaktadır. Fakat yargılama hukuku tamamen pratik olma gayesini güden bir teknik hukuk olarak kabul edildiği müddetçe yargıca kimin birșey söylemeye hakkı olabilir? Maddî bakımdan doğru ve bu sebepten âdil olan hüküm ile sırf yargılamanın dış görünüşü itibariyle gayeye uygunluğu arasındaki fikir uyuşmazlığında iyi niyetli yargıcın kararı açık olacaktır. $\mathrm{O}$, yargılamanın akıșının kanunî intizamının tam olarak müzakere edilmesini ve aydınlatılmasını tercih edecektir. Nihayet avukatlar da yarğlama hukukunun kesin müddetlerine açık olarak karşı koymaktadırlar. Onlar müddetin kaçırılmış olması halinde eski hale getirmenin ancak taraf veya vekilinin ağır kusuru bulunduğu takdirde kabul edilmemesini istemektedirler (5). Onların bu isteğinin yargilama ve meslek riskinin sosyalize edilmesi, yani bunun başkalarının sirtına yüklenmesi yolunda bir deney olarak yorumlanmaması gerekir. Bu teklifler daha ziyade yargılama hukuku müddetlerini sadece gayeye uygun bir düzenin faktörleri olarak kabul eden makul bir düșünce tarzıyla izah olunabilirler. Sadece düzen pahasına, arukatı müddeti kaçırmak suretiyle meslekî görevini yapmakta kusur ettiği ve müvekkilinin hakkını kaybetmesine sebep olduğu șeklinde ağır ithama maruz bırakmanın uygun bir çözüm șekli olarak kabulï kolay olmayacaktır.

Yargılama hukuku kurallarının adalet değeri sorunu birçok başka örneklerle de aktüelleştirilebilir. Fakat yine de son olarak âdil hükmün kıstaslarının söz konusu olacağı âşikârdır. Önemli olan husus, bir hükmün mükemmel bir vakıa kontrolünü bertaraf eden, bu vakıa kontrolünün sonuçlarını önemsiz olarak gösteren veya maddî hukukun yanlıs olarak uygulanışının düzeltilmesini engelleyen bir yargilama hukuku kuralına dayanması halinde de âdil olup olmadığı ve niçin âdil olduğudur. Bizim meselemizin nezaket arzederı böyle bir duruma dûçar olması, yargılama hukuku kurallarının gayesinden anlaşılır. Bu kurallar gayelerini içlerinde taşımazlar. Dâvada söz konusu olan, gösteriş olsun diye eksiksiz delil

(5) Fritz Ostler, Anwaltspflichten und Anwaltschaftpflicht im Prozess (Yargılamada avukatların görevleri ve avukatlığın ödevi), Neue Ju. ristische Wochenschrift (Yeni haftalık hukuk dergisi), 1965, 1785 vd., $2031 \mathrm{vd}$. 
toplama, ya da mükemmel bir sevki idare ile bir duruşma süresi yaratmak değildir. Duruşma ve delil tesbitinin sadece hazırlamak zorunda oldukları hükmün esasını teșkil etmeleri yönünden bir değerleri vardır. Bu bakımdan bir kuralın yargılama hukuku vakıalarının âdil bir tanzim şeklini ihtiva edip etmediği daima dâvayı sonuçlandıran kararla belli olur. Böylece daha şimdiden önemli bir ara sonuç elde edilecektir: Yargılama hukuku kuralları hiçbir zaman bizatihî gaye değildirler, aksine dâva ile güdülen gayeye erişmek için bir vasıta olmak durumundadırlar. Sırf formaliteye uysun diye yürütülen şekilciliğin hukukî bir değeri yoktur. Șeklî durumlar üzerinde gayeye aykırı bir ısrar șüphesiz ki, ardında haks1z gayeler gizlenen bir taktik olarak hissedilecektir. Fakat böyle bir anlayış önemli olduğu derecede yetersizdir de. Zira bu doğrudan doğruya, münferit bir yargılama hukuku kuralı ile hüküm arasında bir izafiyet kurar. Dâvada önemli olan hükmün muhtevasından ziyade verilmesi olsayd, belki de bununla yetinebilirdik. Fakat o zaman da yargılama kuralları ancak bir hükmü gerçekleştirmeye elverișli iseler yeter derecede gerekçelendirilmiş olurlardı. Fakat böyle anlaşılan kural kararın doğruluğu için bir garanti olamazdl.

Yargılama hukukunun böylesine dar bir mütalâası herşeyden evvel Goldschmidt (6) tarafından israrla istenmiștir. Goldschmidt'in yargılamanın ötesini araştırmayan ve yargılama dışı ölçülere göre değerlendirilen hükmün doğruluğu meselesini şuurlu olarak belirten saf usulî düşünce tarzı, yargılama hukuku ile maddî hukukun birbirlerinden kolaylıkla ayrılabilecekleri faraziyesine dayanır. Fakat bu șart ancak, yalnız hukukî tesirlerin nazarı itibara alınması ve bu müşahedenin muayyen șekilde sınırlandırılması halinde doğrudur. Șüphesiz ki, bir hüküm maddî hukuk ilișkilerini düzenleyen bir sözleşmeye oranla daha başka tesirleri haizdir. Esasen hükümden beklenen, maddî hukukî duruma hiç dokunmaması, sadece onu tespit etmesidir. Fakat bu ayırım her hüküm için söz konusu değildir. Bir kollektif şirketi sona erdiren kılıklayıcı bir hüküm, ortakların şirketi devam ettirmeme hususunda anlaşmış oldukları bir sözleșmeye nispetle daha bașka bir tesiri haiz değildir. Eğer hükmün ortaklığın mukadderatı üzerine olan etkisi tamamen bir tarafa bırakılarak, bunun tesirinden sadece kesinleşmiş kararlarla olan usulî bağlantı anlaşılmış olsaydı, ancak o zaman bir usulî tesirden söz edilebilirdi. Fakat yargılama kurallarının şartları incelenecek olursa, yargılama hukukunun maddî hukuktan

(6) Der Prozess als Rechtslage, 1925. 
ayrılabileceğine dair olan inanç tamamen dayanaksız bir hale gelecektir. 3iz usulî yönden hukukî sonuçlar doğuran çok sayıda maddî hukuk karakterli kanunî unsurlarla karşılaşmaktayız. Yargılamada dâvacı durumunda olan kimse bir takım maddî hukuk ilişkileriyle bağımlıdır. Hukukî halefiyetin kanunî unsurları aynı zamanda taraf değişiminin usulî sonucunun bağlantı noktası durumundaclır. Yargılamanın alacağı şekil çekişmeli olan maddî hukuk ilişkisinin nev'ine bağlıdır. Boşanma dâvası için geçerli olan yargılama kuralları mamelek dâvasında uygulananlarm aynı değildirler. Yine değişik birtakım kurallar da ceza hukuku veya idare hukuku sahasına hakim bulunurlar. Fakat eğer biz bir yargılama kuralının adil bir hükme erişmek için elverişli bulunup bulunmadığı sorusunu soracak olursak, o zaman maddî vakıa ile hukukî sonuç, yani o kuralın şartları ile müeyyidesi arasındaki ilişkiyi değerlendirmiş oluruz. Bu bakımdan biz usulî bir inceleme yoluyla yalnız hukukî sonuçlarla yetinemeyiz.

Eğer nazarlarımızı usulî tesirlerin ötesinde tarafların hayat münasebetlerine ilişkin dâvanın sonuçlarına çevirecek olursak, bu durum daha belirli bir hal alacaktır. Maddî hukukî duruma aykırı olan bi: hüküm, sadece iddia edilen bir hakkın mevcut olmadığını tespit etmekle kalmaz; aksine kesinleşir kesinleşmez dâvacının tanınmıyan hakk1 kabul ettirmek yönündeki her türlü imkânını yokeder. Dâvacı bu durumda pratik olarak o hakkı kaybetmiş durumdadır. Bu hükmün adil olup olmadığına dair bir soruyu yasaklayan yargılama hukukuna has düşünce, onun fiilî geçerliğini hukuk dışı delillerle gerekçelendirmek zorundadır. Bu metot hükmün maddî adalet prensiplerine aykırılı̆̆ını yargıçlar hegemonyasını bir sonucu olarak izah eder. Hukuk, -hukukun otoritesi ișlemediği anda-, hukuk düzeninin yanı başında yer alan ve uyuşmazlık halinde sosyolojik otorite prensibine göre bu düzene tekaddiim eden ikinci, somut bir düzen yaratan otoriteyi meşrulaştırır (7).

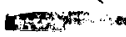

Maddî hukuka has bu mukadder sonuçtan kurtulunmak istend:ği tak:dirde, izole edilmiș olan usulî düşünceden vazgeçmekten başka çare kalmayacaktır. Bu düșünce metodu, bu sorunu yargilama kurallarının adalet değerine göre metafizik dâva anlayıșı olarak hukuk alanından kovmak suretiyle, usulî tesirlerin geçerliliğini artık ancak kuvvet prensibine göre izah edebilecektir. Buna göre, yarģılama hukuku hukuk düzeninden çıkarılmakta ve hukukî

(7) Jannes Goldschmidt, Der Prozess als Rechtslage, 1925, s. 213. 
değer ölçülerinin yerine bu değer ölçülerine önem vermeyen sözde bir sosyolojik takdir konulmaktadır.

Usulî takdir metodunun, yargılama hukuku ile maddî hukukun birbirinden itinayla ayrılması gerektiğine dair istemi doktrinde pek bilinçli bir taraftar bulamamıştır. Gerçi yargılama hukukunun maddî hukuktan ayrılması söz konusu olduğu müddetçe bu metot geniş ölçüde kabul edilmiștir. Fakat yargılama hukuku içinde boş kalan sahaya bu hukuk dalına bugün halâ hakim bulunan kamu hukukuna has değer ölçüleri sokulmuştur. Bu katkıyı yargılamanin devletin yargı organları önünde yürütüleceğine dair olan gerçek haklı kılar. Şayet bunlar hukukî strüktür şekillerine sokulacak olurlarsa, o zaman yargılamada taraflarla mahkeme arasında, kamu hukukuna tabî kilınan hukukî ilişkilerin teessüs etmiş olduğu görülür. Fakat bundan bizim kanunumuz bakımından dolaysız birtakım sonuçlar, ancak, kamu hukukunun bütününün mütecanis karakterde değer ölçüsü düșüncelerinin egemenliği altına girmiş olması halinde görülebilir.

Bu birlik eğilimine karşı yargılama hukuku ilmi uzun süre direndi. Bu hukukun halen mevcut durumunun merkezî bir ilmî kavramda tespit edilmesi ve güçlendirilmesi onun metodik ilkelerine tamamen uygun düșmekteydi. Zira yargılama hukuku alanındaki kamu hukuku ilişkilerinin en önemli unsurunun, tarafların doğru bir hüküm verilmesine dair olan sübjektif haklarında bulunduğu kabul ediliyordu. Dâva hakkı (8) olarak tanımlanmış olan bu hak bugün bizi damgasını vurduğu sistematik öneminden dolayı değil de, daha çok hukukî ve ahlâkî muhtevası sayesinde cezbetmektedir. Dâva hakkında biz liberal bir hukuk devletinde ferdin haiz olması gereken bağımsızlı̆̆ının, nefse olan güveninin bir sembolünui görürüz. Bu hal devleti hizmetkâr bir rolün kabulüne zorlamaktaydı. Fert kendi özel çıkarlarının zafere ulaşması için devletten hizmet etmesini istemekteydi. Fakat dâva hakkı sadece yargılamada ileri sürülen hukukî iddianın maddî doğruluğunun değil, aksine tarafların dâvadaki tutumlarının da zorunlu bir sonucuydu. Bunun anlamı bizzat tarafların dâvanın sonuçlanması için önemli derecede bir sorumluluk tașımaları ve dâvanın akıșını aynı derece-

(8) Adolf Wach, Der Feststellungsanspruch (Tespit hakk1), Ein Beitrag zur Lehre vom Rechtschutzanspruch (Dâva hakkı doktrini hakkında makle), Festgabe der Leipziger Juristenfakultaet für Bernhard Windscheid zum 22. Dezember 1888 (Leipzig Hukuk Fakültesi'nin Bernhard Windscheid için 22 Aralık 1888 tarihli armağanı); Der Rechtsschutzanspruch (Dâva hakk1), Zeitschrift für Zivilprozess (Medenî Yargilama Hukuku Dergisi, Bd. 32, s. 1 vd. 
de serbest olarak şekillendirebilmeleri demek oluyordu. Kısacası: Ferdin kendi somut hukukî uyușmazlığında devlete karşı haiz bulunduğu âdil bir hüküm istemek hakkı, yargılama hukukunun hak arayan şahsa bahşetmiş olduğu hürriyetin sorumlu şekilde kullanılması şartına bağlıydı. Bundan dolayı dâva hakkı, yargılama huhukunuı, kamu hukukunun diğer bölïmlerine karşı bağımsızlığını garanti eden bir faktör olmaktaydı. Burada fert tabî olan durumda değil, aksine bilerek, kendinden emin olarak isteyen hür bir hukuk süjesi statüsündeydi. Gerçi liberal hukuk devletinin idare hukukuna da sübjektif kamu hukukunun bünyesi yabancı sayılmazdı. Bu daha ziyade doğrudan doğruya devlet ve idare hukukunda gelişmiş ve oradan yargılama hukukuna naklolunmuștur. Fakat idare hukukunun ön plânında sübjektif hak bulunuyor ve bu devletin hürriyet ve mülkiyet sahalarına olan tecavüzlerine karșı bir koruma hakkı teşkil ediyordu. Buna karșıllk dâva hakkı ferde, devletin adlî organları kanalıyla sağlamakla yükümlü olduğu müsbet bir ifa, bir görev isteme hakkı vermekteydi. Fakat dâva hakkı aynı zamanda medenî yargılama hukukunun medenî hukukla kenetlenmesini de sağlamıș olmaktaydı. Zira taraflarca iddia ve müdafaada ileri sürülen maddî hukukî durum, dâva hakkının içerisine alı-ımıș oluyordu. Bu hak hukukî iddianın doğruluğunu gerekli kılmak suretiyle, maddî karakterli medenî hukukun, kamu karakterlli yargılama hukuku ile bir bütün teșkil etmesini sağlıyordu.

Șu halde dâva hakkı içinde sübjektif kamu hukukunun soyut yapısı jzafî bir muhtevayla doldurulmuş oluyordu. Bu suretle yargı gürevinin devletin idarî eylemlerine karşı bağımsızlığı korunmakta ve kamu hukukunun genel karakterli değer ölçülerinin yargilama hukukuna münakaşasız olarak kabulleri önlenmiş olmaktaydi.

Yargilama hukukunun daha sonraki gelişimi için dâva hakk1 dokt rininin maruz kaldığı șiddetli kritik karakteristiktir. Dâva hakkını. bugün ancak tarihî bir değer ifade etmesi, yargılama hukukuıun sadece şekil yönünden bünye değiştirdiği anlamına gelmez. Bunu dâva hakkına karşı ileri sürülen deliller gösterirler (9). Bunlara göre: Taraflardan birine daha bașlangıçtan uygun bir hüküm verilmesini isteme hakkı bahșetmek, mahkemenin

(9) Burada pek çokları için misal olarak sadece Leo Rosenberg'in (Lehrbuch des deutschen Zivilprozessrechts, 9. Aufl., 1961, § 90, s. 443 ff.), kit abının daha birinci baskısında bile bulunan (1927, § 89 IV) açıkla. maları gösterilebilir. 
taraflar karşısında haiz olması gereken durumuyla bağdaşamaz. Devlet dâvada münferit bir ferde karșı özel bir yargılama hakkı değil, fakat genel bir yargılama ödevi yerine getirmektedir. Yargilama hukuku, belli yarglama hallerinde yargica aslinda gerekçelendirilmiş olan bir dâvayı (meselâ dâvacının duruşmaya gelmomesi veya delillerini vaktinde arzetmemesi gibi sebeplerle) reddetmek imkânını verir. Bu durumda dâva hakkına ilişkin teori, devletin yargılama düzeninde dâva hakkının zedelenmesini emretmek durumuna düşerdi. Fakat aynı hukukun yargıca aynı zamanda hem dâva hakkının ifasını hem de ifa edilmemesini emretmesi imkânsız olduğu içindir ki, dâva hakkı teorisinden vazgeçmek gerekir.

$\mathrm{Bu}$ delillerde fert ile devletin hukukî ilișkilerinin değișik șekilde ele alınmaları ve devletin yargılama görevinin yepyeni bir tarzda anlaşılması kendini gösterir. Buna göre medenî yargılama hukukunda ön plânda artık fertlerin çıkarlarının korunması değil, aksine toplumun çıkarları yönünden hukukî düzeni sağlayan devletin asayiş fonksiyonu yer almaktadır. Yargılama hakkına karşı yapılan hücumların, kanun metinlerinin ve reform tasarılarının tarafların yargılamadaki egemenliklerine son verdikleri, onların kendi haklarının kullanılmasına ilișkin sorumluluklarını daralttığı ve yargıcın sevkedici kudretini kuvvetlendirdiği bir zamana raslaması tesadüf değildir (10).

Yargılama hakkından uzaklaşmakla alş̧ılmış yargılama hukuku kavramının liberal unsurları kaybolur. Geriye devletin asayiși sağlama görevi kalır. Liberal hukuk devleti alelâde hukuk ve asayiş devleti haline gelir. Yargılama hukukunun kamu hukuku dalına bağlanması böylelikle bașka bir önem kazanır. Devletin yargı görevi, idarî fonksiyonlarıyla aynı kademeye konulur. Bunlardan herbiri aynı ölçüde hukukla kayıtlı asayiș sağlamak durumunda oldukları için de aradaki sınırlar silinir. İdare hukukunda gelișen kamu karakterli prensipler yargılama hukukuna naklolunurlar. Devletin yargı ödevi, düzenleyici ve emniyet sağlayıcı idare ile aynı ölçüde olan bir asayiș fonksiyonu olarak anlașilacak olursa, bu takdirde usulî hukukî sonuçlar devlet otoritesi ve ferdin itaat göreviyle izah edilebilirler. Otoritenin yegâne tahdidi, bağımsızlık ve mülkiyete yapılacak müdaheleler için konulmuş olan kanunî kayıtlardır. Fakat eğer müdahele yargılama kanunu ile meşru hale getirilmişse, bu takdirde taraflardan biri-

(10) 1924 ve 1933 tarihli medenî usul kanunlarıyla 1931 tarihli tasarı. 
nin dâvada katlanmak zorunda kaldığı kanuna dayanan her zarar, bozulan düzene karşı kesin bir reaksiyon olarak görülür. Kesinleșriș olan hüküm kanunî temele dayanan bir devlet eylemi olarak itaat istediğ̣i için tarafları bağlar.

Maddî hukukî duruma bakılmaksızın duruşmaya gemeyen dâvacının dâvasının reddine veya aynı durumdaki dâvalının, dâvacının isbat edilmemiș olan iddiasına göre mahkûm edilmesine sebep olan gıyap kararı, devlet otoritesine karşı olan itaatsizliğin bir müeyyidesi olarak izah olunabilir. Bu görüş açısından, yargilama hukukunun müeyyideleri maddî medenî hukukla tezat teşkil eder şekilde ortaya çıkar. Bunlar kendilerini hakl çıkaracak sebebi artık tarafla:ın birbirine karşı olan hukukî ilişkilerinde değil, sadece kamu hukuku alanında, devletin asayiş ve emniyet sağlayıcı fonksiyonlarinda ararlar.

Bu görüş doğrudan doğruya yanlı̧ olmamakla beraber, tam da sayılmaz. Asayiş sağlamak ve devam ettirmek şüphesiz ki yargılamanın bir ödevidir ve devlet otoritesine karşı itaatın sağlanması ise, otorite keyfî ve hiçbir bağ tanımıyan kuvvetle karıștırılmadığı müddetçe, devletin yükümlü olduğu bir hukukî görevdir. Bununla beraber asayiș, otorite ve emniyet kendi bașlarına birer hukukî değer değildirler. Asayiş hukuk ile bağımlı olmalıdır, hukukî emniyet hukuk fikrinin rehberliğine muhtaçtır, nihayet otorite ise kayıtlı sorunnluluğu şart kılar. Otoritenin kelime anlamı «nüfuz» demektir. Bugün biz onu nüfuza dayanan geçerlilik iddiası olarak anlamaktayız. Hukuken bağlayan otorite bu bakımdan onu kullanacakların hukuka uygun nüfuz sağlayarak bunu muhafaza etmesini ve sorumluluğuna hukuk indinde bu suretle lâyık olmasını șart koşar. Fakat sorumluluğun muhtevası, bu sorumluluğun doğruluğunun belirtildiği birtakım görevlerde gösterilmiş̧tir. Hukukun sosyal hayata yabancı ve dolayısıyla adaletsiz bir soyutlukla siritıp kalmaması için, ödevlerine ve sorumluluk alanlarına uygun olarak ayrıntılarının belirtilmesi gerekir. Devletin ödevi, kendisinden emniyet ve asayiș isteyen ve hukukî bir özü bile bulunmayan bir mahreç telkin etmek değildir. Liberal hukuk devleti de görevini böyle anlamamıștır. Emniyet ve asayiș onun hedefi değil, aksine hürriyet ve mülkiyeti korumak ve özel insiyatif ile endïstrileşmiş toplumun gelișimini sağlamak için bir vasıtadır. Fakat emniyet ve asayiş sağ̣lamak yolundaki gayretlerini bir hedefe, hukukî bir değere yöneltmeyen șeklî bir hukuk devleti (11), bünyesinde, asayiş gay-

(11) Karş. Herbert Krüger, Allgemeine Staatslehre (Genel Kamu Hukuku Bilimi) 1964, s. 776 vd. 
retlerini ölçebileceği adalet ölçülerinin bulunmayışı sebebiyle gerçek anlamda bir hukuk devleti olamaz.

Eğer devlet otoritesi kendisine verilen ödevleri lâyıkıyla yerine getirmişse, bu takdirde biz devlet fonksiyonlarını mütecanis hukukî ölçülerle ölçmek isteyen bir sisteme haklı olarak itimat etmeyiz. Nasıl ki modern idare hukuku idarenin fonksiyon sahalarına uygun olarak taazzuv etmiş bir yeni sistem arıyorsa (12), yargılama hukuku ilmi de kendisini kamu hukuku prensipleri denilen genel kuralların münakaşasız olarak kabul edilmesinden korumak zorunluluğundadır; kaldı ki daha yakından incelenecek olurlarsa bu kuralların hattâ kamu ve idare hukukları için bile genel karakterde bir geçerlilik iddia edebilecek durumda olmadıkları görülür. Zira bunlar devletin bu asrın bașlarında kendi hukukî sorumluluğunu üzerlerine teksif etmiş olduğu alanlardan elde edilmiş olan sadece soyut karakterli değerlerdir.

Talep edilen fonksiyonel müşahede tabii olarak yargılama hukuku içinde de bir ayırım yapmayı zorunlu kılar. Bütün yargılama tipleri için geçerlilik iddiasında bulunan genel bir yargılama hukuku ilmi, ancak adalet değeri sorunundan, söz konusu usulî düşünce tarzının da yaptığı gibi, tamamen vazgeçmek, yahut adalet ölçülerinin emniyet ve asayiș kavramlarıyla bunların adalet muhtevaları kaybolacak derecede soyut olarak ifade edilmeleri şartıyla mümkündür. Medenî yargılama hukukuyla, ceza yargılama hukukunun müşterek olan tek yönleri, bunların her ikisinin de devlet mahkemelerince uygulanıyor olmasında görülür. Bunların ikisinde de kamu hukuku karakterli ilişsiler düzenlenmiştir. Fakat muhtevaları ele alınacak olursa, aralarında pek çok farkın bulunduğu meydana çıkar. Bu durunı sadece çeşitli yargılama kanunlarına şöyle bir göz atmak sureitiyle anlaşılmakla kalmaz; sosyal faaliyet ve dolayısıyla devlete her iki alanda yükletilen sorumlulukda da en azından aynı derecede farklar görülür. Savcının bir cinayet sanı̆̆ını dâva etmesiyle, kiralayanın kiracıdan birikmiş kira taksitlerini talep etmesi birbirlerinden tamamen başka șeylerdir. Bu durum karşısında yargılama kurallarının adalet değerlerine olan talep o konuyla uğrașanların özel bir meselesi haline gelmiştir. Bunun içindir ki, ben sahamın dışına çımamak ve sadece içerisinde fertlerin

(12) Peter Badure Göttingen'deki ilk dersinde, Verwaltungsrecht im liberalen und im sozialen Rechtsstaat (Liberal ve sosyal hukuk devletinde idare hukuku), Recht und Staat (Hukuk ve devlet), Sayı 328, 1966, s. $22 \mathrm{vd}$. 
birbirleriyle olan özel hukukî uyuşmazlıklarının karara bağlandığı yargılarna usulünden, medenî yargılama hukukundan söz etmek istiyorum.

Medenî yargılama hukukunun bâriz özelliği yargılamanın sonuçlarının doğrudan doğruya dâvaya katılmıș olan tarafların özel hukuk münasebetlerine ilişsin olmasında görülür. Bunu en açı olarak, yargılama dıșı, maddî hukukî duruma aykırı olan bir hükümde görürüz. Eğer dâva kesin olarak reddolunmuşsa, o zaman dâvacı kabul edilmeyen hakkının tanınmasını sağlayacak resmî bir devlet mercii bulamaz. Onun durumu hakk ${ }_{1}$ kaybetmiş olmaktan daha iyidir denilemez.

Șu halde hüküm veren devlet bu hükümle tarafların özel hukuk ilişkileri için bağlayıcı karakterde olan bir düzen sağlar. Bu suretle devlet taraflar arasındaki bir menfaat çatışmasını önlemiş̧ olur. Medenî yargılama hukukunda karşılaşılan menfaatler kaideten devletin menfaatlarıyla uyuşmazlar. Devletin menfaati, taraflardan birine veya diğerine, onun maddî menfaatların mek için birşeyler vermek yönünde değildir. Devletin istediği daha ziyz.de, taraf menfaatları arasında âdilâne bir uzlaşmayı sağlamaktır. Bunun içindir ki, devletin ödevleri medenî yargılama hukukunda ceza yargılamasında olduğundan daha azdır. Devlet tarafları medenî yargılama için zorlamaz, aksine ancak taraflar kendisine bașvurunca harekete geçer. Taraflar kendi özel menfatları bak1mından uyușamadıklarından dolayıdır ki devlet, bunlar haklarını korumak için kendi insiyatiflerini kullanıncaya kadar bekler.

Medenî Yargılama Kanun koyucusu, buna göre; medenî yargllama clanında devletin ödevinin esas itibariyle yalnı taraflardan biri tarafından getirilen delillerin takdirinden ve taraflarca isbat olunan vakıaya hukukun uygulanmasindan ibaret olduğu sonucuna ulașmaktaydı. Devletin burada sadece yardım edici, hizmet edici bir fonksiyonu vardı. Devlet, yarglama hakkmın tarifinde de isabetli clarak belirtildiği üzere, taraflara karşı yükümlü olduğu bir eda (hizmet ifası) getiriyordu.

Bıı düșünce tarafların yargılamada haiz bulundukları tanzim serbestisinden aynı ölçüde faydalanabilmeleri esasına dayanır. Fakat bu şart bize bugün artık șüpheli gözükmektedir. Bu anlayıș, devlet bütün fertlere ayn imkânları tanıyacak olursa, hürriyetin korun abileceği fikrine dayanmakta, fakat bu meyanda, aynı ölçüde ist fade edildikleri takdirde aynı imkânların, ancak aynı hürriyeti sağlayabileceklerini takdir edememektedir. Daha somut bir 
söyleyişle: Taraflara vakıaya ilişkin olan birbirine zıt tavsiflerini serbestçe arzetmek ve isbat etmek imkânı verildiği takdirde, karar için önemli olan vakıanın en iyi bir şekilde aydınlatılabileceğine dair olan düşünce tarzı, tarafların yargılama hukukuyla ilgili imkânların karışık sisteminin farkına varmamaları, bu imkânları elde etmekten sosyal bir takım bağlar dolayısıyla alıkonulmamaları ve bir tarafın imkânlarını diğer taraf aleyhine kötüye kullanmaması șartına bağlıdır. Onun içindir ki modern yargılamada yargıcın ödevleri daha geniștir. $O$, tarafların haiz bulundukları yargılama hukukuna ilişkin imkânlardan faydalanmalarını, gayeye uygun dilekçeleri vermelerini, vakıaları etraflıca arzetmelerini, delilleri kullanmalarını ve diğer tarafın zararını gerektirecek şekilde bilerek yalan söylememelerini sağlamak zorundadır. Şu halde menfaatlar dengesi artık arzolunan vakıaya maddî hukukun uygulanması ile değil, yargılama hukuku imkânlarının da birbirleriyle uyuşmasıyla elde edilecektir.

Genişletilmiş bu görev sahasi için sorumluluğu devlet taşır. Yanlış olan hüküm için devlet ancak, fakat ancak yargıcın delilleri yanlış değerlendirmesi, hukuku yanlış uygulaması veya yargılama imkânlarının kendisine bırakılmış olan tesviyesinde başarısızlı̆̆a uğradiğı nisbette sorumlu olacaktır. Devlet hizmete uygun bir yargılama dïizeni yaratmak, fertler arasında kaçınılması imkânsız olan hataları etkisiz bırakmak için çok dereceli bir yargılama sistemi kurmak, yargıçları kanuna ve hukuka bağlamak ve onu bú suretle bütün diğer bağlardan kurtarmak, nihayet, yargıcı itina ile yetiștirmek ve adaylar arasından çok sıkı sınavlarla seçmek suretiyle sorumluluğuna uygun şekilde hareket etmiş olacaktır.

Fakat bu garantiler de, bir dâvada bütün yargı kademelerinin görevlerini bașarıla yürütememelerini tam olarak önleyemez. Yanlıș hükümlerden bütün bütün kaçınmak imkânsızdır. Fakat eğer yalnız doğ̣u olan hüküm bağlayıcı olarak kabul ve ilân edilecek olursa, bu takdirde devlet görevini lâyı̆̆ıla yerine getirmemiş olacaktır. Çünkü taraflar, mahkeme dıșında halledemedikleri uyușmazlıklarını ilelebet devam ettirmek için mahkemeye gitmezler. Onlar uygun bir süre içinde uyuşmazlığı halleden bir hüküm beklerler. Bunu onlar devlet emniyet ve asayiși hakim olsun da birbirlerini sıkboğaz etmesinler diye değil, aksine ilerdeki tasarruflarına temel teşkil edebilecek ve dolayısıyla hür, sorumlu kararların şartı olabilecek berrak ilișkiler aradıkları için isterler. Asayiși sağlamak için olan değii, sorumlu bir hürriyetin șartı bulunan düzen, doğru bir karar elde etmek için bütün garanti ve gayretlere rağmen âdil bir menfaatler dengesini sağlayamıyan bir hükmü haklı gösterir. 
Bu pratik tecrübeyle de doğrulanır. Tarafları haklarını özel hakem mihkemelerinde aramaya sevk ve bu suretle devlet yargisinı bertaraf eden motiflerde adaletin ne ölçüde güven bulduğu açıkça görïlüir. Tahkim sözleşmesinin devletin yargıcının hukuku uygulamasina veya vargılamayı idare edişine karșı bir güvensizlik sonucu aktedildiği ender görülen bir șey değildir. Eğer bu peșin hükümlere dayanmamaktaysa, o zaman bunun yargıcın seçimi, yetișmesi, kompetanlığı ve olaylara olan yakınlığı hedef alınan bir kritik olduğ̆u kabul edilerek, ciddiyetle üzerinde durulması gerekir. Fakat hakem mahkemesi için atılacak adım ekseriya dâvanın kısa sürmesi isteğinde aranmalıdır. Birçok hakem yargılamaları bir derece içinde çözümlenir. Şu halde taraflar için dâvanın çabuk sonuçlanması, çok dereceli yargılama sisteminin sağladığı garantiden daha önerniidir.

Fakat medenî yargılamada aleyhe olan hukukî sonuçlar sadece mahkemenin işlediği hatalardan ileri gelmez. Bizzat taraflara yargılamanın sonuçlanması için sorumluluk yükletildiğ̀i müddetçe, onların, yargllamanın mahzurlarını kendi tutumlarında aramaları gerekir.

Vakıavı arzetmek ve deliller göstermek tarafların görevidir. Tarafla ca arzedilmeyen fiilî olaylar hükümde nazarı clikkata alınmaz. Arzedilen vakıalardan hasım tarafından itiraz edilmeyenler için delil getirmeye lüzum yoktur. Bunlar doğru olarak kabul edilirler. İsbat vasıtası olarak yalnız tanık varsa ve beyyine külfeti kendisiาe diișen taraf tanık göstermezse, o zaman isbatı gereken olay isbatı imkânsız kabul edilir. Dâvacı kararlaştırılan günde celseye gelmediğ takdirde dâvası reddolunur. Dâvalı duruşmaya gelmeyecek olursa, dâvacının ileri sürdüğüi vakıalar doğru kabul edilir ve eğ̣er dâvacının iddiaları erişilmesi istenilen hukukî sonucu haklı gösterir karakterde iseler, dâvalı mahkûm edilir. Yargılama hukuku doktrini bunu iddia, beyyine ve yargılamada hazır bulunma yükünün sonuçları olarak izah eder. Gerçi bu kavramlar olayları doğru tasvir ederler, fakat hiçbir şey açılamazlar. Öte taraftan yargılamanın kamu hukukunca yapılan izahında bu sonuçlar itaatsız olan için müeyyideler, cezalar veya düzen tedbirleri olarak ortaya çıarlar. Bu izah da işin mahiyetine uygun değildir. Çünkü ceza ve asayiș düşünceleri, ihmalkâr olan tarafın katlanmak zorun. da olduğu mahzurun diğer tarafa fayda sağlamasını gerektirmez.

Eğer taraflara dâvanın sonuçlanması yolunda bir parça sorumluluk yükletilmișse, bu, yargılamada haklarını kabul ettirebilip ettiremiyeceklerini ve nasıl kabul ettireceklerini görmek için onlara 
serbestî sağlamak gayesiyle yapılır. Bu usulî yenilik doğuran serbestî, onlara sübjektif maddî özel hukukun bahşettiği hukukî kudretin mantıkî bir sonucudur. Nasıl ki onlar kendilerine maddî sübjektif haklar ile sağlanan malları kanunun çizdiği sınırlar içinde kalmak kaydıyla diledikleri gibi kullanırlar ve bunlardan faydalanırlar veya hiç faydalanmadan olduğu gibi bırakabilirlerse, hakları üzerinde tasarruf edebilir ve bunlardan feragat edebilirlerse, aynı şekilde dâvada da hukukun uygulanmasının nev'i ve derecesi üzerinde bizzat karar verebilirler. Hiçkimse dâvacıdan, hakkını takipten vazgeçerek, hakkında bir gıyap kararının çıkmasını sağlaması$\mathrm{n}$ isteyemez. Yine hiçkimse dâvalıyı, dâvacının iddiasına karşı hakkını korumaya zorlayamaz. Dâvalı münakașasız olarak kararın aleyhine çıkmasını sağlarsa, bu kendi bileceği bir iştir. Burada ceza veya asayiş tedbirlerinden söz etmek isabetli olmaz. Tarafa verilen bu zarar, kendisi böyle istediği ve onun iradesine hukuk düzeni tarafından saygı duyulduğu için haklıdır. Serbestî bahşeden bir haktan faydalanmamayı ceza ile tehdit etmek, bizzat hürriyeti yok etmek demek olacaktır.

Fakat yargilama hukukunun mahzurlu sonuçlarının sadece bunları istiyene veya bilerek göze alana değil, aksine ihmalkâr olana da zaı arı dokunur. Bu sonuç bütün hukukî düzenlerde hürriyet haklarının karşıt kavramı olarak karşılaștığımız bir hukukî prensiple haklı kılınır. Hürriyet haklarını kullanmayan kimse, bunu kaybeder. Çünkü hukuka dayanarak verilen serbestî keyfîlik değil, soı umlu bir bağımsızlıktır. Sorumluluk hürriyete başkalarının haysiyetleriyle çekilen sınırların bir sonucudur. Başka bir şahsın da serbest kararlar vermeye hakkı vardır. Onun da düşüuncelerine saygı duymak gerekir. Fakat o ancak hasmının davranıșlarına güven duyarsa karar verebilir. Kararını verdiği anda da durumu değiștirecek ve hasmının serbest karar verme șansını yok edecektir. Bu mülâhazalar maddî özel hukukta eskiden beri hakkın kullanılmasının kısıtlanması olarak kabul edilegelmiş olan hak düşmesinin esaslarıdır. Yargılamada sukut düşüncesinin söz konusu olmaması şaşlacak bir șey olurdu. Sukut fikri asıl aktüalitesini hakkın kullanıldığ 1 en önemli yer olan mahkemedeki yargılamada bulur. Yargılama hukukunun bahşettiği yenilik doğurma imkânlarından faydalanmayan kimse dâvayı istediği gibi şekillendirme şansını kaybeder ve onun hakkını kullanması caiz olmaz. Yargılamada bu sonuç ların oldukça kısa ve kesin olarak belirtilmiş süreler içinde ortaya çıkması, dâvada taraflardan beklenilen şeyin, haklarının kullanılması olmasıyla izah edilebilir; çünkü yargılama, içerisinde kısa bir müddet zarfında hakkın kullanılması yönünde önemli kararla- 
rın alın tığı bir safhadır. Bu gibi kararlar ancak, eğer diğer tarafın yaptı̆̆ı ve kaçındığı şeyler bağlayıcı ise mümkündür. Bu bakımdan yargılaraa hukuku müeyyidelerinin yanlış hükme sevkeden ve düzen uğruna adaleti hiçe sayan sırf gayeye uygun tedbirler olarak anlaşılnamaları gerekir. Bunlar maddî hukukla tenakuz halinde bulunarı bir hükmün verilmesini sağlamalarına rağmen, gerek yargilama hukuku ve gerek maddî hukuk yönünden aynı derecede bağlayıcı olan bir hukukî prensibe dayanan âdil sonuçlardır.

Medenî yargılama hukukunda, kaçırılan bir süreye karșı gidilecek eski hale getirme için mevcut șartların kolaylaştırılabilip kolaylaștırılamıacağına dair olan aktüel mesele, bu mülâhazalarla bugüne kadar nazarı dikkata alınmamıştır. Kaçırılan bir süre karşısında'ki her ihmalkârlık, hasmın kanunî bakımdan kazanmış olduğu duruma bir tecavüz teşkil eder. Bu bakımdan avukatların, eski hale getirmeyi sadece ağır kusur halinde kabul etmemek yönündeki gz:yretleri, șeklî düzen prensipleriyle değil, hasmın korunmaya değer çıkarlarıyla çatıșır karakterdedir. Müddetin kaçırılmasının müeyyidesi, sübjektif şartları icra edilebilen bir disiplin cezası değil, bilâkis bir menfaatlar uzlașmasıdır. Burada söz konusu olan mesele, taraflardan birinin ihmalinden diğer tarafın sorumlu tutuluf tutulmaması gerektiğidir. Bunun cevabı maddi hukukta hak dïsșmesi prensibinin sağlanması gayesiyle geliștirilen esaslara göre verilmek gerekir. Buna göre hak düșmesinin sonucu bir kusurun varlığını gerektirmez. Bu sonuç ancak ilgili kimsenin iddiasını derineyan etmek için kendisinden beklenileni tam olarak yerine getirmiş olması halinde gerçekleşmez. (13) Bu prensipler eski hale getirme sebeplerinin halen geçerli olan kaideleriyle bağdaşır karakterdedirler.

Yargilama hukuku ile maddî hukuk arasında burada incelenen bağlan i Almanya'da uzun zaman kapalı kalmıș olan bir konudur. Fikrimizce, bu tutum yüzünden ne yargilama hukukuna ve ne de maddî hukuka iyi bir hizmette bulunulmamıștır. Son zamanlarda bizim yargılama hukukumuzun bağımsız, șeklî bir takım hukukî prensipler iopluluğu değil, aksine maddî hukuk ve onun adalet ilkeleriyle sıkı sıkıya bağlı bir hukuk dalı olduğu görüșü yerleşmiştir. Bu suretle biz, bizleri uzun müddet diğer Avrupa devletlerinin yargılama hukuku ilminden ayırmış bulunan çapraşık bir yoldan geri dênmüş̧ ve yargılama hukuku kaidelerinin adalet değerleri sorununu müsbet olarak cevaplandırabilmek için tekrar birtakım ön şartlar kazanmış oluyoruz.

(13) S.jergel-Siebert, BGB. 9. Aufl., 1959, § 242 Anm. 186. 